DOI: $10.17148 /$ IARJSET.2021.8861

\title{
Traditional healthy foods and practices during pregnancy in India: Mini Review
}

\author{
Varleen Kaur $^{1}$, Harminder Kaur ${ }^{2}$ \\ ${ }^{1}$ UG - Home Science (Dietetics), Government Home Science College, Panjab University \\ ${ }^{2} \mathrm{UG}$ - Nutrition and Dietetics (Honours), Punjab Agricultural University
}

\begin{abstract}
The birth of a newborn is a moment of tremendous joy for the mother, and every mother has the complete right to experience it. In India, pregnancy is considered a normal physiological phenomenon, and often hospital check-ups are only done when a medical issue is being faced by the women. This behaviour can sometimes be dangerous for both the mother and baby. Pregnancy-related complications are sharply increasing in developing countries like India. Poor maternal nutritional status of women before and during pregnancy due to their own childhood undernutrition, low level of BMI at conception, inadequate gestational weight gain due to poor dietary choices has serious implications on the mother and the baby. As in all cultures, certain beliefs and practices exist during this period of pregnancy and in rural areas of India, this is even more common. Most food practices and traditions of India have stemmed from deeply rooted traditions and customs. This often leads to hindrance in the consumption of healthy foods which can help in the prevention of chronic diseases during this stage and as well as at a later period of life. This minireview reveals the important traditional healthy foods across various regions of Indian which can be beneficial during the gestational period and also focuses on pregnancy beliefs among women. Relevant papers were identified from Google Scholar, PubMed, and ScienceDirect by using various combinations of terms related to recommended foods in pregnancy.
\end{abstract}

Keywords - pregnancy, traditional foods, maternal health, nutritional factors, Indian Health foods, Indian women, food practices.

\section{INTRODUCTION}

The World Health Organization (WHO) estimated that 536,000 maternal deaths occur every year worldwide, out of which 136,000 happens in India (1). Over the last 2 decades, the Government of India has introduced various policies and programs at the national level for a healthy motherhood experience. There is very little evidence that maternity has become significantly safer in India. The status of women is generally low in India, except in a few states of the southern and eastern parts. Women lack the empowerment which is required for decision making and often the decision-making is influenced by family practices, socio-economic status, unscientific family traditions, and taboos. The period of pregnancy is very sensitive and of utmost importance in a woman's life. Pregnancy increases women's nutritional requirements and yet causes aversions to nutritional healthy foods. Most societies further restrict pregnant women's diet with family taboos. It has been established that women from less privileged societies of India tend to suffer from undernutrition of different grades and their bodies are not able to tackle the physical workload and increased nutritional demand during pregnancy (2). The health of the infant and successful lactation depends entirely on the diet consumed by the mother during the gestation and lactation period (3). The fact that cultural beliefs and practices play a role in determining the nutritional status of a community cannot be ignored. Since maternal nutrition plays a hugely important role in pregnancy outcomes, ignorance regarding dietary needs can cause life-threatening damages to the health of newborns. Sood and Kapil (4) studied the nutritional status of pregnant mothers and $64 \%$ of them believed that overall decreased food intake for the first six months of pregnancy results in a smaller baby, making delivery easier. Such kind of frequent pregnancies with poor nourishment put mothers at great risk during delivery. Traditional beliefs may not always follow modern biomedical norms of maternal nutrition, fetal growth, and safe delivery (5). These beliefs and practices are linked to the existing century-old cultural ethos and to the upbringing and education of women. The woman herself feels the need to consume specific food items to maintain good health during the pregnancy period (6). A study was done in Hyderabad (7) revealed that a large number of women consume specific food items during pregnancy and lactation period this suggests that women attach much importance to it. However, poverty, nonavailability of certain foods, wrong beliefs, and at times ignorance by the families force women to avoid specific food items and those foods are considered as taboos. These taboos may include nutritional foods also, and this kind of behavior can be observed during any stage from the first trimester to the postpartum period. A study was done in Tamil Nadu, South India (8) studied the diet of thirty pregnant women in their last trimester for comparing the nutrient intake 


\section{DOI: 10.17148/IARJSET.2021.8861}

with the recommendation. It was found that a diet being quite rich in rice, leads to micronutrient deficiency. The diet lacked energy intake and all nutrients except fat when compared with Indian recommendations. This study also revealed that factors like education level, family type, pregnancy number did not seem to have a negative effect but factors like eating customs and economy appeared to influence the women's food choice. The objectives of this review are to document the beliefs and customs followed by pregnant women in India and to reveal traditional Indian foods which can be beneficial in this pregnancy journey.

\section{INFLUENCE OF MATERNAL NUTRITION ON PREGNANCY OUTCOMES}

Adequate nutrition during the preconception and pregnancy period is crucial to the health of the infant and mother (9). Mother's nutrition from the time of conception is an important factor in determining the infant's metabolic pathway and physical health in the future. The fetus relies on maternal nutrition for development. Moreover, good nutrition during this period prepares the mother for delivery and post-natal recovery. Improved nutritional intake can potentially reduce pregnancy-related complications like gestational diabetes and pre-eclampsia along with their long-term morbidities. Caloric restriction or any kind of weight loss diet is not recommended during this period. These kinds of dietary patterns often lack insufficient energy intake and micronutrients which are crucial for the formation of a healthy fetus. Maternal obesity or being overweight before conception can put the mother at a high risk of developing gestational diabetes and metabolic syndrome diseases (10). Observational studies done by Barker and colleagues suggested that maternal diet is an important factor in determining infant and placenta size (11-13). Additional delivery complications have been repeatedly shown to be associated with maternal overweight and diabetes (gestational and type 2). This includes pro-longed birth, birth asphyxia, shoulder dystocia, injuries to the baby and the mother, increased use of instruments during vaginal deliveries and caesarean sections and postpartum hemorrhaging (14-15). Another prominent feature of modern day obstetrics is the increasing incidence for Large-for-gestational-age babies. The rapid increase in weight, metabolic characteristics especially in developed countries are a direct cause for this issue. All of these concerns are directly or indirectly linked with diet.

\section{TRADITIONAL BELIEFS AND PRACTICES DURING PREGNANCY IN INDIA}

Nutrition plays a major role in maternal and child health and it is widely recognized that optimum nutrition in early life is the foundation for long-term health. A healthy maternal dietary pattern, along with adequate maternal body composition, metabolism and placental nutrient supply, reduces the risk of maternal, fetal and long-term effects in the offspring (16). However, this aspect is inevitably interlinked to perceived notions and beliefs concerning food to be consumed by pregnant women (17). In any community, pregnancy is a critical period of life and response towards pregnancy and childbirth varies from culture to culture (18). A study conducted among tribal women of fakir gujri, Srinagar, Jammu and Kashmir details the simple at-home herbal measures that are put to use by the tribal women folk to treat the discomforts of pregnancy, aid healing and bring about therapeutic effects to the body. Special attention is paid to the diet of women. It is of critical importance because her diet has a direct bearing on her health and indirectly the baby. Care is taken to procure the choicest food item in terms of variety (pure cow milk, desi eggs, desi rice, desi ghee) and hygiene (19). It also highlights the age-old practice of the ceremonial bath taken after the baby is delivered. The water used for bathing is a decoction of herbal plants called "Losse Ghasse" that are believed to have therapeutic properties (20). Poor maternal nutrition adversely affects pregnancy and birth outcomes, particularly vulnerable are the rural women in a rural setting. A lactating mother's nutritional requirement should meet the needs of herself and that of an infant. There is a need for health education programs in rural areas regarding nutrition which will, in turn, improve maternal and child health (17). Another genre of concern was food that increased body heat. It is believed that certain foods when consumed increased the body temperature and were thus avoided. Some women believe that excessive eating during pregnancy may result in a large fetus and difficult labor. Fiji-Indians may believe that it is the responsibility of others to satisfy a pregnant woman's cravings. A baby which dribbles excessively indicates that the mother was not taken care of properly during her pregnancy. There are no restrictions applied to physical activity during pregnancy. Women from lower socioeconomic classes may continue their daily activities until labor starts, including daily house chores. Women from higher socioeconomic classes are usually nurtured by their families. Some women may take herbal medicines to promote the development of a male fetus (21).

\section{HOT AND COLD FOODS}

Nutrition-related practices during pregnancy are based on a belief that 'hot' foods are harmful and 'cold' foods are beneficial. Pregnant women are advised to attain balance by eating cold foods and avoid hot foods namely papaya, banana, coconut, pineapple, red chilies, jackfruit, meat, and egg as pregnancy generates a hot state (22). Cold foods are recommended in early pregnancy to avoid miscarriage. Hot foods are encouraged during the last stages of pregnancy to facilitate labor (23). In the state of Andhra Pradesh, many pregnant women are told that foods like papaya and pumpkin 


\section{International Advanced Research Journal in Science, Engineering and Technology}

Vol. 8, Issue 8, August 2021

\section{DOI: 10.17148/IARJSET.2021.8861}

are too "hot" for the baby. In parts of Gujarat, white foods including milk, yogurt, and bananas are routinely avoided because they are "too cold" (24).

\section{TRADITIONAL HEALTHY FOODS}

Traditional Indian foods have been prepared for many years and preparation varies across the country. Traditional wisdom about the processing of food, its preservation techniques, and their therapeutic effects have been established for many generations in India. Indian traditional foods are also recognized as functional foods because of the presence of functional components such as body-healing chemicals, antioxidants, dietary fibers, and probiotics (25). According to ayurvedic concepts, food is responsible for different aspects of an individual including physical, temperamental, and mental states (26).

\section{A. Grain-based Foods}

\section{Idli}

Idli is a fermented product prepared from rice and black gram batter by steam cooking (27). Idli is a white colored, small, round, and spongy product. Black gram (Phaseolus mungo. L.) is the primary ingredient having natural fermentation microflora and acts as the substrate for the fermentation of batter (28) Fig.1(a). Black gram and rice are used in the ratio of 1:2 during batter preparation. Fermentation of idli batter improves the nutritional and protein efficiency value (29). The major microorganisms involved in the leavening process are heterofermentative lactic acid bacterium, Lactobacillus mesenteroides.

\section{Dosa}

Dosa is another fermented dish like idli mainly found in the south Indian region. It is a highly seasoned pancake, containing rice and black gram as primary ingredients (30). Susupe dosa, another type of dosa, is prepared from the boiled red raw rice. For the purification of lactating women's blood, it is advised to give at least three susupe dosas twice a day without rice gruel (ganji) (31).

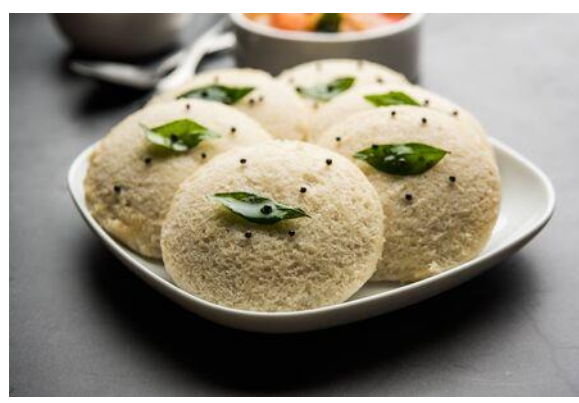

(a) (12rf.com)
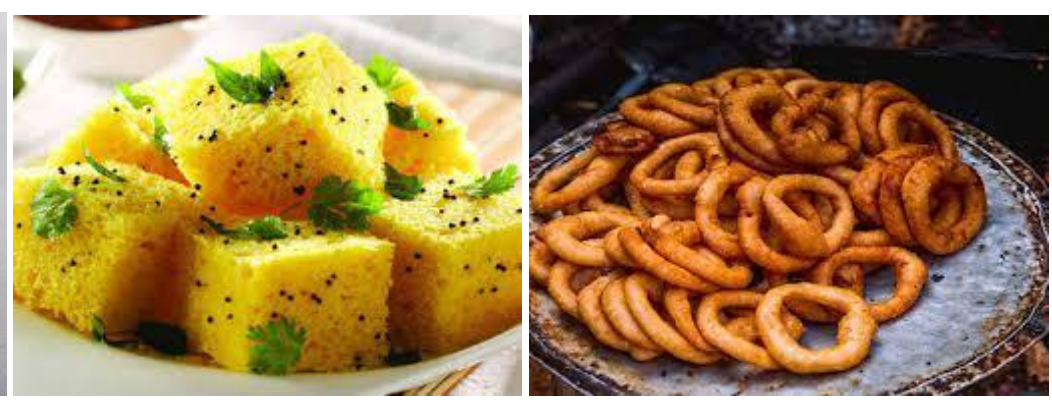

(b) (indiamart.com)

(c) (tasteatlas.com)

Figure - 1. Grain-based foods

\section{Ambali}

Ambali is a finger millet-based fermented semi-liquid product of south Indian states, Karnataka and Tamil Nadu. The preparation method includes mixing finger millet flour with water to make a thick batter and followed by cooking and fermentation. The fermentation process decreases the leucine to lysine ratio (from 3.6 to 4.1 ) and increases the concentration of thiamin, riboflavin, and tryptophan and the bioavailability of minerals (32).

\section{Dhokla}

Dhokla is prepared from the fermentation of Bengal gram and rice (33). Yeast is used for the culture since it produces folic acid and helps in making food spongy by increasing the batter volume (34),(25). Compared with the unfermented batter, the antioxidant property of fermented batter is high (35) Fig.1(b). 


\section{International Advanced Research Journal in Science, Engineering and Technology}

Vol. 8, Issue 8, August 2021

DOI: $10.17148 /$ IARJSET.2021.8861

\section{Hawaijar}

Hawaijar is an alkaline-fermented soybean product consumed daily as a source of protein in Manipur. It is unsalted and has a characteristic flavour and stickiness (36). The organism mainly involved in the fermentation of this product is Bacillus spp. (37). During the preparation of hawaijar, bamboo baskets, banana leaves, or healthy fig leaves are used, which helps in fermentation and results in a better quality of the product. Hawaijar consists of soluble proteins ranging from $26 \%$ to $27 \%$ [38]. Presence of Bacillus spp. gives high fibrinolytic activity to the product (39). It is rich in proteins.

\section{Selroti}

Selroti is a rice-based fermented food, which is spongy and ring-shaped. It is consumed in Sikkim and Darjeeling. Local variety rice or rice flour is soaked overnight in cold water and then water is decanted. Soaked rice is pounded into small powder using wooden mortar and pestle. Then the rice is mixed with wheat flour, sugar, butter, and condiments such as cloves, cardamom, coconut, nutmeg and cinnamon. Milk or water is used for kneading the powder into a soft dough for easy flow. The batter is left to ferment at ambient temperature for 2-4 hours followed by molding into a ring and fried. It is served as a confectionery product (40). The nutritive value of selroti is similar to idli and has a good amount of digestible proteins. Lactobacilli, Pediococcus, Enterococci, and Leuconostocs are the principal microorganisms present in selroti (41) Fig.1(c).

\section{B. Fruits and Vegetable-based foods}

\section{Bale dandu palya}

Bale dandu palya is a food made from the stem of banana plants. The stem is cut into pieces and made into cubes and boiled, followed by seasoning with chili, salt, coriander, curry leaves, grated coconut, and turmeric powder. It is good for digestion-related issues (42) Fig.2(a).

\section{Jackfruit seed chutney}

Jackfruit (Artocarpus heterophyllus Lam. Fam. Moraceae) is an ancient fruit consumed in Southeast Asia. The edible part of jackfruit includes fruits and seeds. The bioactive compounds such as antioxidants, carotenoids, phenolic compounds and other phytonutrients improve the medicinal value of jackfruits and its seeds (43).

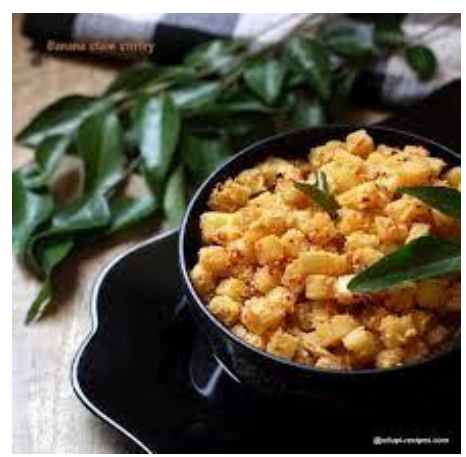

(a) (udupi-recipes.com)

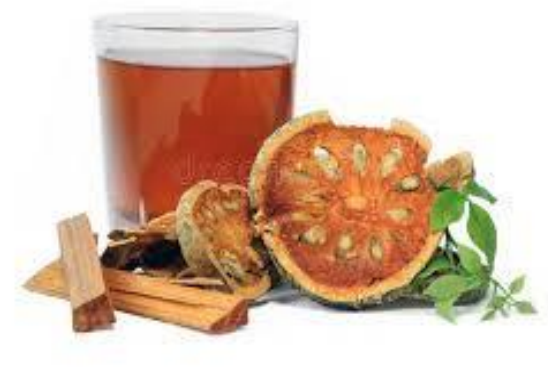

(b) (dreamstime.com)

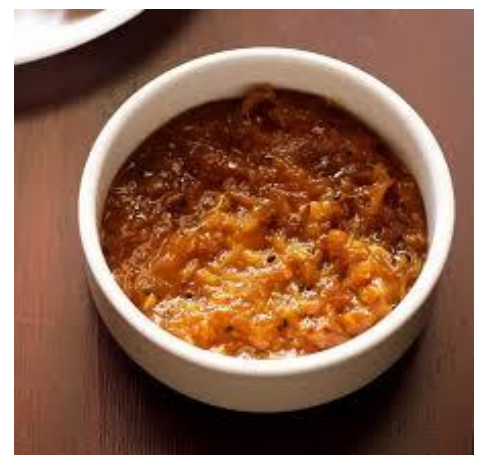

(c) (vegrecipesofindia.com)

Figure - 2. Fruit and vegetable-based foods

\section{Bael fruit syrup}

Bael fruit (Aegle marmelos) is grown in wild areas of India. Unripe bael fruit exhibits antimicrobial effects and is mainly used for diarrheal treatment in Indian communities (44). Aegeline, an alkaloid present in the leaves of bael tree, is used as a dietary supplement (45) Fig.2(b). A beverage is prepared from the pulp of bael fruit. 


\section{International Advanced Research Journal in Science, Engineering and Technology}

Vol. 8, Issue 8, August 2021

DOI: $10.17148 /$ IARJSET.2021.8861

\section{Mango peel chutney}

Peel is an edible part of mango. Mango peels are rich sources of dietary fibers and bioactive compounds such as carotenoids, vitamin C, and vitamin E (46) Fig.-2(c). Mango peel chutney is a traditional food found in south Karnataka. Ripened or un-ripened mango peels are used for the preparation of chutney.

\section{Green leafy vegetable-based foods}

\section{Spinach roti}

Spinach (Spinacia oleracea) belongs to the family Amaranthaceae. Preparation of roti using spinach is very common in south India. Spinach is a good source of protein and iron (47) Fig.3(a). It is recommended for girls during menstruation and for pregnant and lactating women as well.

\section{Saag}

Saag is a leaf-based dish prepared in the northeast part of India. Green leafy vegetables such as spinach, basella, mustard leaf, or collard greens are used in the preparation of saag (48) Fig.3(b). Saag is prepared from a variety of green leafy vegetables and hence possesses a significant amount of minerals and vitamins.

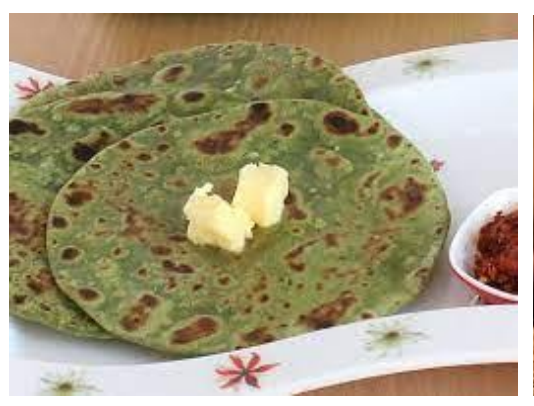

(a) (foodviva.com)

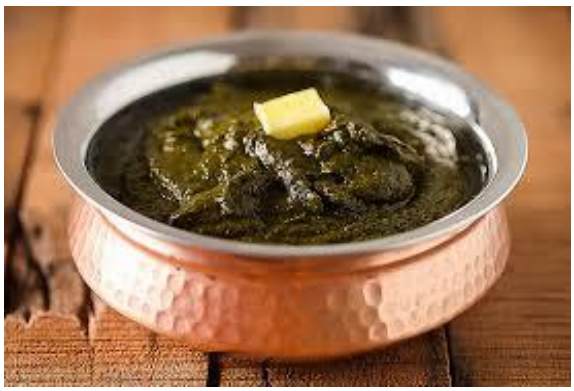

(b) (divinetaste.com)

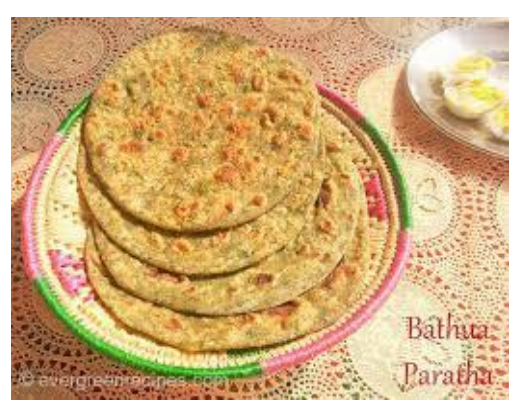

(c) (evergreeenrecipes.com)

Figure -3 . Green leafy vegetable-based foods

\section{Bathua paratha}

Bathua (Chenopodium album L.) belongs to the family Chenopodiaceae, a common herb used in the preparation of foods in India. Leaves of the plant contain ascaridole, which is used in the treatment of hookworm and roundworm infection (49) Fig.3(c). Bathua paratha is a breakfast food that is available only in the winter season.

\section{Milk-based foods}

\section{Dahi (Indian yoghurt)}

Traditionally, dahi is a naturally fermented milk product obtained from boiled cow or buffalo milk and soured using mixed lactic cultures. It is used in the daily diet as a potential source of B-complex vitamins, folic acid, and riboflavin (50). Dahi is rich in lactic acid bacteria and demonstrates a probiotic effect, which helps in intestinal health (16), (52). As storage time increases the sourness of dahi increases, mild heat treatment can be given to increase the shelf life. Chilika curd is a region-specific food; it can be found in Odisha state in India and has a longer shelf life than normal dahi. It is prepared from chilika buffalo milk and is concentrated by boiling. The concentrated milk is poured into pretreated bamboo containers covered with leaves and incubated to prepare the curd. Microbial analysis of chilika curd shows that it contains inherent thermotolerant Lactobacilli. The bamboo used in the preparation has certain antifungal agents such as dendracin (53).

\section{Saffron Milk}

Saffron milk is a highly beneficial spice with many amazing medicinal properties and can provide a number of benefits during the gestational period. Saffron helps to increase blood flow to the digestive organs, enhancing digestion as well as improving metabolism. Intake of saffron can also relieve as well as prevent acidity. It provides relief from the pain 


\section{International Advanced Research Journal in Science, Engineering and Technology}

Vol. 8, Issue 8, August 2021

\section{DOI: 10.17148/IARJSET.2021.8861}

caused by cramps. It soothes and relaxes the muscles, reducing muscular pain. It has some incredible anti-inflammatory properties that can protect from infections (54).

\section{Rabdi}

Rabdi is a famous dairy preparation in the northwest part of India. It is a lactic acid-fermented milk product with pearl millet (55) Fig.4(a).

\section{Ginna}

Ginna is a colostrum-based Indian sweet. It is also known as junnu, posu, or kharvas in different regions of India. Colostrum is a rich source of immune components such as immunoglobulins, and iron-binding lactoferrin protein, and nutrients such as vitamin A and minerals (56) Fig.4(b). Ginna is prepared from the 1st day's thick milk (colostrum) of a cow after calving. The colostrum is mixed with normal milk to dilute and with sugar/black jaggery powder. Cardamom is then added for taste followed by cooking in a closed vessel in a pressure cooker. After cooking is complete, the final product is cut into pieces and served with roti, dosa, or idli.

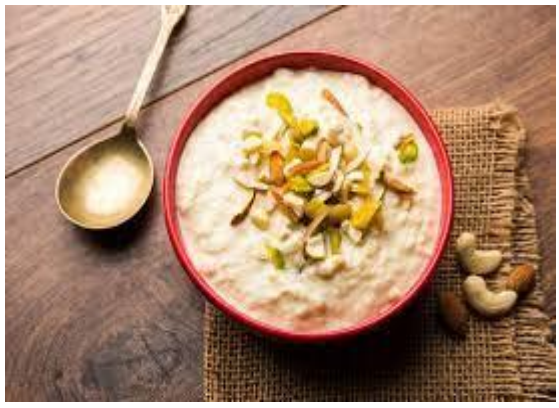

(a)(stock.adobe.com)
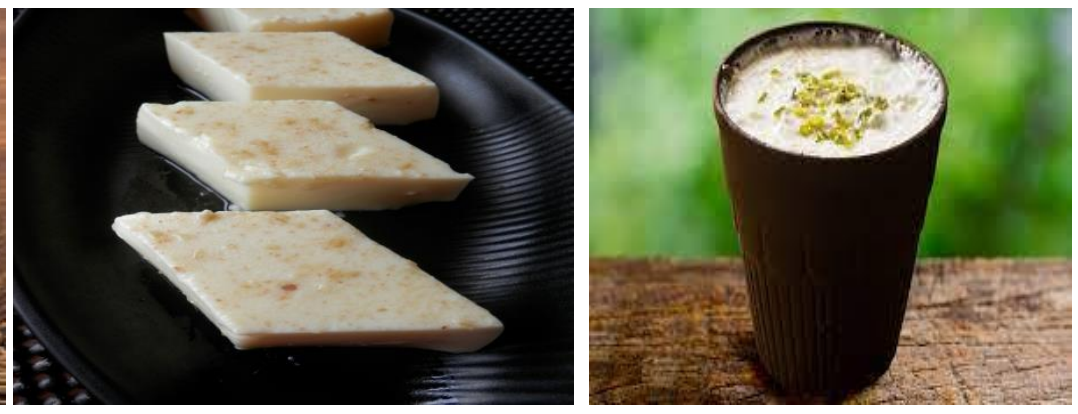

(b) (neetuskitchen.wordpress.com)

(c) (istockphoto.com)

Figure-4. Milk-based foods

\section{Lassi}

Lassi is a traditional milk beverage consumed in the summer season for refreshment and is prepared from dahi (Indian yoghurt. Lassi is a probiotic product due to the presence of L. acidophilus, and S. thermophilus as active cultures [58]. Based on the use of ingredients in lassi, it is classified as salty lassi or sweet lassi (57), (58)Fig.4(c).

\section{CONCLUSION}

India has been growing rapidly on the socioeconomic front but the development in maternal health is comparatively slow. The western diet is becoming extremely popular in India among young mothers. Though it is very important to plan your meals according to the latest recommended dietary allowances (RDA) set by the ICMR, however our country India is full of nutritious superfoods which need to bring back in our daily lifestyle. The diversity of traditional health foods of India has evolved according to the climatic conditions, culture and cropping practices of that particular region. Efforts at the national level are required to scientifically document the health benefits of Indian traditional foods and practices for the benefit of both Indian and international communities.

Conflict of Interest - Authors declare that there is no conflict of interest.

\section{REFERENCES}

1- World Health Organization. "Maternal mortality in 2000: estimates developed by UNICEF and UNFPA. Geneva: World Health Organization, 2007; 4: 16." p.(www. who. int/reproductive-health/MNBH/maternal_mortality_2000/index. html accessed on 20 January 2004).[Google Scholar] (2008): 36

2- Chatterjee, Meera, and Julian Lambert. "Women and nutrition: reflections from India and Pakistan." Food and nutrition bulletin 11.4 (1989): 1-16.

3- Leslie, Joanne. "Women's nutrition: the key to improving family health in developing countries?." Health policy and planning6.1 (1991): 1-19.

4- Sood, Ajay K., and Umesh Kapil. "Traditional advice not always good." World Health Forum. Vol. 5. No. 2. 1984.

5- Nag, Moni. "Beliefs and practices about food during pregnancy: implications for maternal nutrition." Economic and political weekly (1994): 24272438.

6- Leela, M. Sai, and B. R. Busi. "The effect of physiological state on the nutritional status of women." Man in India 75.3 (1995): $221-229$.

7- Surekha, R. Assessment Of Infant Feeding Practices Cost And Attitude Of The Mother Towards Infant Feeding In Hyderabad City. Diss. APAU; 


\title{
International Advanced Research Journal in Science, Engineering and Technology
}

\author{
Vol. 8, Issue 8, August 2021
}

\section{DOI: 10.17148/IARJSET.2021.8861}

Hyderabad, 1984.

8- Andersen, Lena Theilgaard, et al. "Food and nutrient intakes among pregnant women in rural Tamil Nadu, South India." Public health nutrition 6.2 (2003): 131-137.

9- Van Teijlingen, E. R., et al. "Effectiveness of interventions to promote healthy eating in pregnant women and women of childbearing age: a review." Database of Abstracts of Reviews of Effects (DARE): Quality-assessed Reviews [Internet](1998)

10- Barker DJP. Fetal and infant origins of adult disease. London: BMJ Publishing, 1992.

11- Campbell, D. M., et al. "Diet in pregnancy and the offspring's blood pressure 40 years later." BJOG: An International Journal of Obstetrics \& Gynaecology 103.3 (1996): 273-280.

12- Godfrey, Keith, et al. "Maternal nutrition in early and late pregnancy in relation to placental and fetal growth." Bmj312.7028 (1996): 410.

13- Godfrey, K. M., et al. "Maternal birthweight and diet in pregnancy in relation to the infant's thinness at birth." BJOG: An International Journal of Obstetrics \& Gynaecology 104.6 (1997): 663-667.

14- Galtier-Dereure F, Boegner C, Bringer J. Obesity and pregnancy: complications and cost. Am J Clin Nutr. 2000 May;71(5 Suppl):1242S-8S. doi: 10.1093/ajen/71.5.1242s. PMID: 10799397.

15- Mocanu EV, Greene RA, Byrne BM, Turner MJ. Obstetric and neonatal outcome of babies weighing more than $4.5 \mathrm{~kg}$ : an analysis by parity. Eur J Obstet Gynecol Reprod Biol. 2000 Oct;92(2):229-33. doi: 10.1016/s0301-2115(99)00280-8. PMID: 10996687.

16-Cetin, I., \& Laoreti, A. (2015). The importance of maternal nutrition for health. Journal of Pediatric and Neonatal Individualized Medicine $(J P N I M), 4(2)$, e 040220.

17-Catherin N, Rock B, Roger V, Ankita C, Ashish G, Delwin P, Shanbhag D, Goud BR. Beliefs and practices regarding nutrition during pregnancy and lactation in a rural area in Karnataka, India: a qualitative study. Int J Community Med Public Health 2015;2:116-20.

18-Marshall, L.B. 1985 Infant Care and Feeding in the South Pacific. Gordon and Breach Science Publishers, New York.

19-Bhinish Shakeel, Hummara Azim and Nayeema Jabeen. 2018. Traditional Food and Health Practices during Post-Partum Period: A Study among Tribal Women of Fakir Gujri, District Srinagar, Jammu and Kashmir. Int.J.Curr.Microbiol.App.Sci. 7(08): 1076-1081.

20-Boer H. De. and Lamxay V. 2009. Plants used during pregnancy, childbirth and Post-Partum health care in Lao PDR: A Comparative Study of the Brou, Saey and Kry ethnic groups. Journal of Ethnobiology and Ethnomedicine.

21- Neogi SB, Negandhi PH, Ganguli A, et al. Consumption of indigenous medicines by pregnant women in North India for selecting sex of the foetus: what can it lead to?. BMC Pregnancy Childbirth. 2015;15:208. Published 2015 Sep 4. doi:10.1186/s12884-015-0647-4

22-Nag, Moni. "Beliefs and Practices about Food during Pregnancy: Implications for Maternal Nutrition." Economic and Political Weekly, vol. 29, no. 37, 1994, pp. 2427-2438. JSTOR, www.jstor.org/stable/4401755. Accessed 22 July 2021.

23-Choudhry UK. Traditional practices of women from India: pregnancy, childbirth, and newborn care. Journal of Obstetric, Gynecologic and Neonatal Nursing. 1997;26(5):533-539.

24- Adamsons D. S. (2015, March 25) The myths about food and pregnancy. BBC News. https://www.bbc.com/news/magazine-32033409

25-C. Hotz, R.S. Gibson. Traditional food-processing and preparation practices to enhance the bioavailability of micronutrients in plant-based diets. J Nutr, 137 (2007), pp. 1097-1100

26-B. Ravishankar, V.J. Shukla. Indian systems of medicine: a brief profile. Afr J Tradit Complement Altern Med, 4 (2007), pp. 319-337

27- K.N. Agarwal, S.K. Bhasin. Feasibility studies to control acute diarrhoea in children by feeding fermented milk preparations Actimel and Indian Dahi. Eur J Clin Nutr, 56 (Suppl 4) (2002), pp. S56-S59

28-R. Radhakrishnamurty, H.S. Desikachar, M. Srinivasan, V. Subrahmanyan. Studies on Idli fermentation. II. Relative participation of black gram flour and rice semolina in the fermentation. J Sci Ind Res (C), 20C (1961), pp. 342-345

29-N.R. Reddy, S.K. Sathe, M.D. Pierson, D.K. Salunkhe. Idli, an Indian fermented food: a review. J Food Quality, 5 (1982), pp. 89-101

30-B.D. Palanisamy, V. Rajendran, S. Sathyaseelan, R. Bhat, B.P. Venkatesan. Enhancement of nutritional value of finger millet-based food (Indian dosa) by co-fermentation with horse gram flour. Int J Food Sci Nutr, 63 (2012), pp. 5-15

31-S. Hegde, N. Yenagi, B. Kasturiba. Indigenous knowledge of the traditional and qualified ayurveda practitioners on the nutritional significance and use of red rice in medicine. Indian J Tradit Knowl, 12 (2013), pp. 506-511

32-S. Mbithi-Mwikya, W. Ooghe, J. Van Camp, D. Ngundi, A. Huyghebaert. Amino acid profiles after sprouting, autoclaving, and lactic acid fermentation of finger millet (Eleusine coracan) and kidney beans (Phaseolus vulgaris L.). J Agric Food Chem, 48 (2000), pp. 3081 -3085

33-K. Steinkraus. Handbook of indigenous fermented foods. (2nd ed.), CRC Press, Boca Raton (1995)

34-P. Kanekar, N. Joshi. Lactobacillus fermentum, Leuconostoc mesenteroides and Hansenula silvicola contributing to acetoin and folic acid duringdhokla' fermentation. Indian J Microbiol, 33 (1993), pp. 111-117

35-J.L. Evans, I.D. Goldfine, B.A. Maddux, G.M. Grodsky. Oxidative stress and stress-activated signaling pathways: a unifying hypothesis of type 2 diabetes. Endocrine Rev, 23 (2002), pp. 599-622

36-T. Premarani, G. Chhetry. Evaluation of traditional fermentation technology for the preparation of hawaijar in Manipur. Assam Univ J Sci Technol, 6 (2010), pp. 82-88

37-K. Jeyaram, W. Mohendro Singh, T. Premarani, A.R. Devi, K.S. Chanu, N.C. Talukdar, M.R. Singh. Molecular identification of dominant microflora associated with 'Hawaijar' - a traditional fermented soybean (Glycine max (L.)) food of Manipur, India. Int J Food Microbiol, 122 (2008), pp. 259-268

38-P. Thingom, G. Chhetry. Nutritional analysis of fermented soybean (Hawaijar). Assam Univ J Sci Technol, 7 (2011), pp. 96-100

39-T.A. Singh, K.R. Devi, G. Ahmed, K. Jeyaram. Microbial and endogenous origin of fibrinolytic activity in traditional fermented foods of Northeast India. Food Res Int, 55 (2014), pp. 356-362

40-H. Yonzan, J.P. Tamang. Traditional processing of Selroti-a cereal based ethnic fermented food of the Nepalis. Indian J Trad Knowl, 8 (2009), pp. 110-114

41-H. Yonzan, J.P. Tamang. Microbiology and nutritional value of selroti, an ethnic fermented cereal food of the Himalayas. Food Biotechnol, 24 (2010), pp. 227-247

42-J.B. Jamuna, S. Mahadevamma, S. Vishwanatha, V.S. Paramahans. Effect of banana (Musa Sp. Cultivar Elakki Bale) flower and stem on enzyme 


\title{
International Advanced Research Journal in Science, Engineering and Technology
}

\author{
Vol. 8, Issue 8, August 2021
}

\section{DOI: 10.17148/IARJSET.2021.8861}

activities of intestinal and renal disaccharidases in streptozotocin-induced diabetic rats. J Food Biochem, 34 (2010), pp. 564-580

43-S.B. Swami, N. Thakor, P. Haldankar, Kalse. Jackfruit and its many functional components as related to human health: a review. Comp Rev Food Sci Food Saf, 11 (2012), pp. 565-576

44-S. Brijesh, P. Daswani, P. Tetali, N. Antia, T. Birdi. Studies on the antidiarrhoeal activity of Aegle marmelos unripe fruit: validating its traditional usage. BMC Complement Altern Med, 9 (2009), p. 47

45-T.A. Govindachari, M.S. Premila. Some alkaloids from Aegle marmelos. Phytochemistry, 22 (1983), pp. 755-757

46-C.M. Ajila, S.G. Bhat, U.J.S. Prasada Rao. Valuable components of raw and ripe peels from two Indian mango varieties. Food Chem, 102 (2007), pp. 1006-1011

47-G. Singh, A. Kawatra, S. Sehgal. Nutritional composition of selected green leafy vegetables, herbs and carrots. Plant Foods Human Nutr, 56 (2001), pp. 359-364

48-D. Amit. Sarson ka saag [Internet]. (2014) [cited 31 Aug 2015]. Available from: http://www.vegrecipesofindia.com/sarson-ka-saag/

49-K.R. Kirtikar, B.D. Basu. Indian medicinal plants. Lalit Mohan Basu, Allahabad (1918)

50-R. Sharma, D. Lal. Effect of dahi preparation on some water-soluble vitamins. Indian J Dairy Sci, 50 (1997), pp. 318-320

51-K.N. Agarwal, S.K. Bhasin. Feasibility studies to control acute diarrhoea in children by feeding fermented milk preparations Actimel and Indian Dahi. Eur J Clin Nutr, 56 (Suppl 4) (2002), pp. S56-S59

52-S. Sarkar, A. Misra. Bio-preservation of milk and milk products. Indian Food Ind, 20 (2001), pp. 74-77

53-D.K. Arora, R. Chaudhary, D. Kumar. Indian Chilika curd-A potential dairy product for geographical indication registration. Ind J Trad Knowl, 12 (2013), pp. 707-713

54-_Saied M. (2020, October 29) Saffron During Pregnancy: Benefits, Uses, Side Effects \& More. Kashmirica. https://www.kashmirica.com/blog/saffron-during-pregnancy/

55-U. Mani, S. Prabhu, S. Damie, I. Mani. Glycemic index of some commonly consumed foods in Western India. Asia Pac J Clin Nutr, 2 (1993), pp. $111-114$

56-F.O. Uruakpa, M.A.H. Ismond, E.N.T. Akobundu. Colostrum and its benefits: a review. Nutr Res, 22 (2002), pp. $755-767$

57-S. Patidar, J. Prajapati. Standardisation and evaluation of lassi prepared using Lactobacillus acidophilus and Streptococcus thermophilus. J Food Sci Technol, 35 (1998), pp. 428-431

58-Sarkar P, Lohith Kumar DH, Dhumal C, et al. Traditional and ayurvedic foods of Indian origin. J Ethn Foods. 2015;2(3):97-10 